\title{
APPLICATION OF THE KOSECKI'S METHOD IN DESIGNING OF OFFSHORE WIND POWER PLANTS FOUNDATION
}

\author{
Kamila Międlarz ${ }^{凶}$, Paweł Więcławski \\ Faculty of Civil and Environmental Engineering, Gdansk University of Technology, Gdańsk
}

\begin{abstract}
The concept of offshore wind power plants has been well developed in many European countries. There is no such thing as design of offshore wind power plants according to national tradition. The main problem is the lack of standards and guidelines. Ones being applied are Scandinavian or American methods which are not fully adapted to the conditions of the Baltic Sea. The article focuses on the monopile design, as it is currently the most often used type of offshore power plants foundation. The results from analysis, according to standard wind turbine monopile design methods, were compared with the results obtained from the Kosecki's method. The geometry analyzed in the article goes beyond the scope of defined geometrical and technological coefficients used to determine the stiffness of spring supports. The adopted stages of the analysis allowed to determine the limit of applicability of the Kosecki's method for monopiles loaded horizontally.
\end{abstract}

Key words: pile foundation, monopile, offshore wind power plants, wind energy

\section{INTRODUCTION}

In 2011, and then in 2015 and 2016, the Act of 21 March 1991 on the Polish Republic's sea areas and maritime administration was amended, which resulted in the increasing interest in the subject of offshore wind energy. The location of wind farms, apart from the previously mentioned act, is also determined by the following conditions (Leite, 2015):

- environmental: sea depth, wind strength;

- spatial: fishing zones, zones of military manoeuvres, shipping routes, raw material deposits;

- economic;

- social;

- legal and administrative: birds protection zones and protected areas;

- political.

The pioneering investment in Poland called the Bałtyk Środkowy III (BS III), is to be launched in 2022, and it is another part - the BS II in 2026. The main problem, while designing these structures, is the lack of Polish standards and guidelines. Scandinavian or American methods are used, despite not being fully adapted to the climatic conditions on the Baltic Sea. These standards allow to use various design methods. The basic standards for the design of offshore wind turbines are:

- DNV-OS-J101: Design of Offshore Wind Turbine Structures, 2014;

- DNV-DS-J102: Design and Manufacture of Wind Turbine Blades, Offshore and Onshore Wind Turbines, 2010;

- API-RP 2A-WSD: Recommended Practice for Planning, Designing and Constructing Fixed Offshore Platforms - Working Stress Design, 2002;

- IEC 61400-1: Wind Turbines - Design Requirements, 2005;

- IEC 61400-3: Design Requirements for Offshore Wind Turbines, 2002. 
Most of common approaches are based on the method of partial safety factors. Alternatively or as a complement to analytical methods, the design can be based on the test results or observations of models in a natural or reduced scale.

\section{FOUNDATION CHARACTERISTICS}

The basic structural elements of an offshore wind turbine are: (Fig. 1):

- nacelle - containing electromechanical elements,

- rotor - built with hub and blades;

- tower - tubular construction made of steel or concrete;

- transition piece - connecting the tower with the foundation;

- foundation.

The type of foundation depends on the distance from the shore and on the sea depth. For shallow areas, the best solution is to use gravity based foundations (Fig. 2d) or monopiles (Fig. 2a). As the depth increases, the construction of jackets (Fig. 2c) tripods (Fig. 2b) (often used also in the foundation of drilling units) becomes more beneficial. In deep waters floating structures are the most economical (Fig. 2e).

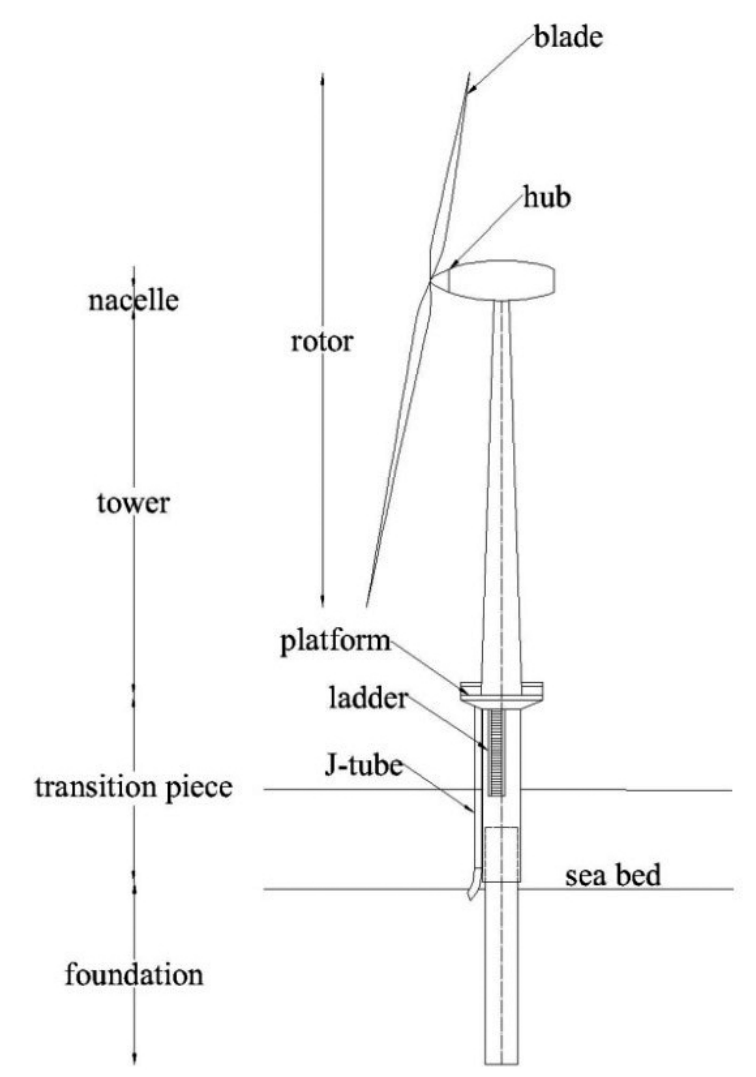

Fig. 1. Elements of an offshore wind turbine

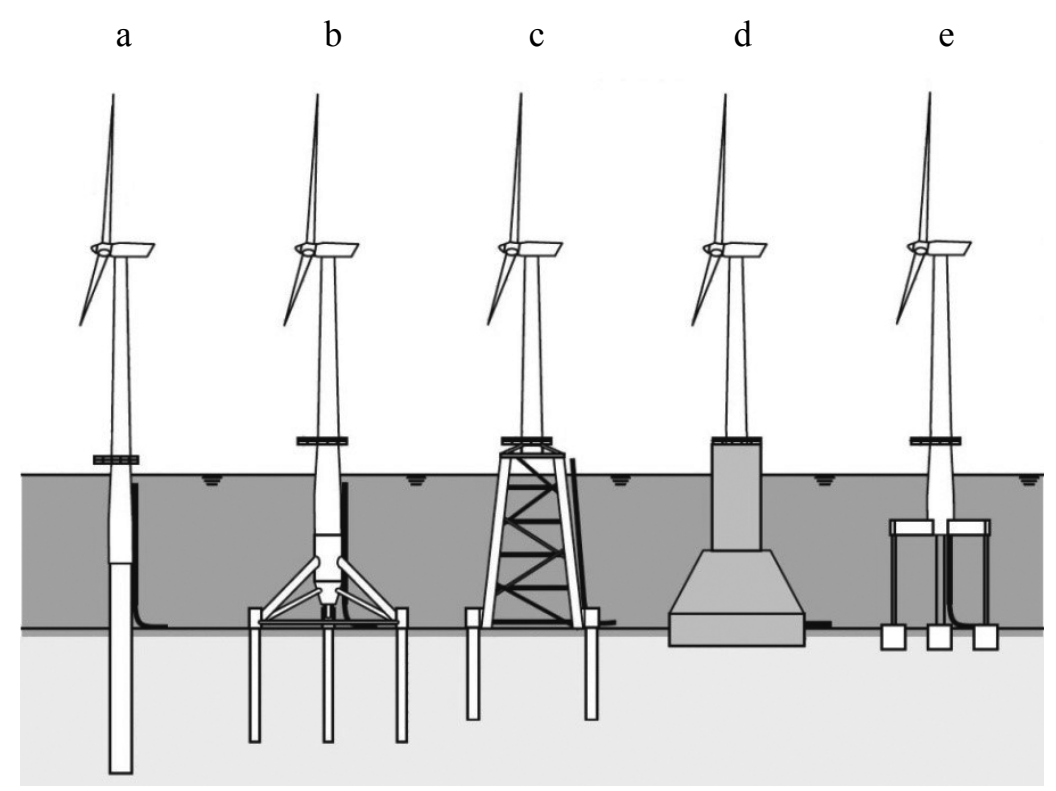

Fig. 2. Wind turbine foundations: $\mathrm{a}$ - monopile; $\mathrm{b}$ - tripod; $\mathrm{c}$ - jacket; $\mathrm{d}$ - gravity foundation; $\mathrm{e}-$ floating foundation (van der Tempel, 2006) 
Currently, most offshore wind farms in Europe are located at depths up to $20 \mathrm{~m}$ and mostly used foundation types are monopiles, accounting for about $76 \%$ of all existing foundations. They owe their popularity to relatively simple production, installation process and to a wide range of exploitation. This is an efficient solution at depths of up to $35 \mathrm{~m}$ and this depth is constantly increasing.

The monopile structure is relatively simple as it is made of a single, steel, cylindrical tube with a diameter of up to $9 \mathrm{~m}$ and a wall thickness of up to $150 \mathrm{~mm}$. Pipes are usually made by rolling and longitudinal welding steel plates. Prepared elements are transported to the wind farm area using transport ships or special platforms towed by tugs.

Monopiles can be driven into the seabed with the use of hammers or impact-rotary hammers, depending on the current environmental conditions and the geological structure of the seabed. After installation, the upper elements of the wind turbine, i.e. the tower, nacelle and blades, are assembled. Depending on the structure of the seabed, the tower can be attached to a monopile directly or via a transition piece.

\section{LOADS AFFECTING OFFSHORE WIND FARMS}

According to the guidelines of the Norwegian classification society Det Norske Veritas (DNV), the loads acting on the offshore wind farm are divided into five categories (Table 1).

In the analysed example, three most important environmental loads were considered (Fig. 3), i.e. wind, wave and sea currents, which is a good starting point for further, more complex calculations.

Normal and extreme wind conditions are distinguished by the DNV standards. Normal conditions are used to assess fatigue loads under standard load conditions, while extreme conditions apply to extreme situations that cause huge loads on the power plant and the surrounding soil.

Wave data for a specific location are collected over a long period of time. If such data for a given area are not available, parameters from outside areas must be transformed to take differences in water depth and changes in the topography of the seabed into account.

Both waves and currents are generated by the wind, therefore all data should be correlated. The speed of

Table 1. Loads (Det Norske Veritas, 2007)

\begin{tabular}{|c|c|c|}
\hline No & Load category & Type of loads \\
\hline 1 & permanent & $\begin{array}{l}\text { weight of the wind turbine: rotor, hub, blades, nacelle, tower } \\
\text { weight of the monopile and transition piece } \\
\text { hydrostatic pressure }\end{array}$ \\
\hline 2 & variable functional & $\begin{array}{l}\text { installation operations } \\
\text { ship impacts } \\
\text { maintenance of the wind turbine } \\
\text { load of the staff, equipment and materials }\end{array}$ \\
\hline 3 & environmental & $\begin{array}{l}\text { wind } \\
\text { wave loads } \\
\text { currents and tides } \\
\text { snow and ice } \\
\text { temperature } \\
\text { soil conditions }\end{array}$ \\
\hline 4 & accidental & $\begin{array}{l}\text { collision impact from vessel, helicopter or other objects } \\
\text { fire } \\
\text { load from large breaking waves }\end{array}$ \\
\hline 5 & deformation & $\begin{array}{l}\text { settlements } \\
\text { temperature loads }\end{array}$ \\
\hline
\end{tabular}




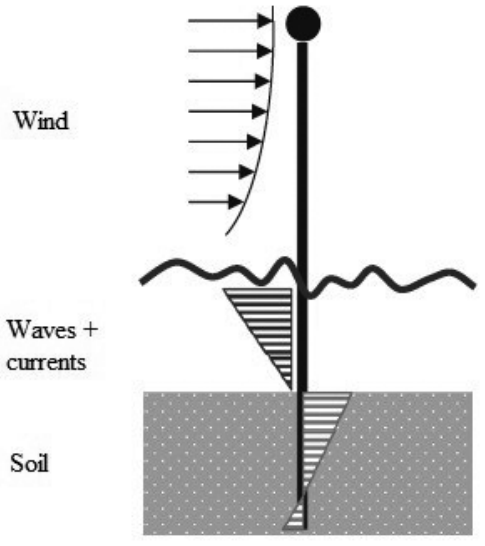

Fig. 3. Environmental loads for the analysed calculation example (van der Tempel, 2006)

sea currents depends on two components: the speed of wind-generated currents and the speed of tidal currents. For the ultimate limit state - ULS, several load combinations are distinguished by using mean values of load types in different time periods or the frequency of occurrence of extreme values. The load occurring in all combinations is a permanent load, the remaining loads used in the combinations are presented in Table 2 .

In the conducted analysis, based on the guidelines presented in DNV Offshore Standard (Det Norske Veritas, 2014) seven load combinations were prepared with the use of the partial safety factors according to Table 3 .

\section{OFFSHORE WIND TURBINE MODEL}

\section{Soil stiffness according to DNV guidelines}

DNV standards recommend the use of $p-y$ curves for the analysis of horizontally loaded piles. The $p-y$ curves give the nonlinear relationship between soil resistance and horizontal displacement of piles under

Table 2. Load combinations for the ultimate limit state

\begin{tabular}{cl}
\hline Combination no & \multicolumn{1}{c}{ Environmental load type and its value } \\
\hline $1 ; 4$ & $\begin{array}{l}\text { wind - extreme sea state - return period: } 50 \text { years } \\
\text { waves - normal operative loads } \\
\text { currents }- \text { normal operative loads }\end{array}$ \\
\hline $2 ; 5$ & $\begin{array}{l}\text { wind - normal operative loads } \\
\text { waves - extreme sea state - return period: } 50 \text { years } \\
\text { currents - normal operative loads }\end{array}$ \\
\hline $3 ; 6$ & $\begin{array}{l}\text { wind - normal operative loads } \\
\text { waves - normal operative loads } \\
\text { currents - extreme sea state - return period: } 50 \text { years }\end{array}$ \\
\hline 7 & $\begin{array}{l}\text { wind - extreme sea state } \\
\text { waves - extreme sea state } \\
\text { currents - extreme sea state }\end{array}$ \\
\hline
\end{tabular}

Table 3. Load factors for the ultimate limit state

\begin{tabular}{ccc}
\hline \multirow{2}{*}{ Combination no } & \multicolumn{2}{c}{ Load factors for: } \\
\cline { 2 - 3 } & permanent loads & environmental loads \\
\hline $1 ; 2 ; 3$ & 1.25 & 0.7 \\
\hline $4 ; 5 ; 6$ & 1.0 & 1.35 \\
\hline 7 & 1.0 & 1.0 \\
\hline
\end{tabular}


lateral load. The pile is modelled as series of beam-column elements, supported by springs applied in the nodes between the elements. Each spring is placed in the middle of a given soil layer and is characterised by one $p-y$ curve.

In case of cohesive soils, $p-y$ curves are presented in dimensionless form of $y / y_{c}$ as a function of $p / p_{u}(y$ actual deflection; $y_{c}-$ critical deflection; $p$ - actual lateral resistance; $p_{u}$ - ultimate resistance).

The value of critical displacement can be determined on the basis of laboratory tests in the triaxial compression apparatus and by using Equation 1 (Det Norske Veritas, 1992).

$$
y_{c}=2.5 \cdot \varepsilon_{50} \cdot D
$$

where:

$\varepsilon_{50}-$ strain which occurs at one-half of the maximum stress in laboratory undrained compression tests of undisturbed soil samples [-];

$D$ - pile diameter [m].

The values of $\varepsilon_{50}$, for the purposes of the analysed example, were assumed on the basis of correlations presented in the literature (Chen and Duan, 2003).

For cohesionless soils, $p-y$ curves are also non-linear but they may be determined from the following Equation:

$$
P=A_{i} \cdot p_{u} \cdot \tanh \left(\frac{k_{\text {init }} \cdot z}{A_{i} \cdot p_{u}} \cdot y\right)
$$

where:

$A_{i}$ - factor to account for cyclic or static loading condition, evaluated by:

$$
A=\left(3-0.8 \cdot \frac{z}{D}\right) \geq 0.9
$$

$p_{u}-$ ultimate resistance at depth $H\left[\mathrm{kN} \cdot \mathrm{m}^{-1}\right]$;

$z$ - depth below soil surface [m];

$y \quad-$ actual lateral deflection [m];

$k_{\text {init }}$ - initial modulus of subgrade reaction $\left[\mathrm{kN} \cdot \mathrm{m}^{-3}\right]$.

$$
k_{\text {init }}=\left(0.008085 \cdot \phi^{2.45}-26.09\right) \cdot 10^{3}
$$

The ultimate resistance depends on the water depth. For shallow waters, the Equation (5) and for deep waters the Equation (6) is used.

$$
\begin{gathered}
p_{u s}=\left(C_{1} \cdot z+\mathrm{C}_{2} \cdot D\right) \cdot \gamma^{\prime} \cdot z \\
p_{u d}=C_{3} \cdot D \cdot \gamma^{\prime} \cdot z
\end{gathered}
$$

where:

$\gamma^{\prime}-$ effective unit weight of soil $\left[\mathrm{kN} \cdot \mathrm{m}^{-3}\right]$;

$z$ - depth [m];

$D$ - pile diameter [m];

$C_{1}, C_{2}, C_{3}-$ coefficients as a function of $\phi^{\prime}$.

$$
\begin{aligned}
& C_{1}=0.115 \cdot 10^{0.0405 \cdot \phi^{\prime}} \\
& C_{2}=0.571 \cdot 10^{0.022 \cdot \phi^{\prime}} \\
& C_{3}=0.646 \cdot 10^{0.0555 \cdot \phi^{\prime}}
\end{aligned}
$$

where:

$\phi^{\prime}$ - effective angle of internal friction $\left[^{\circ}\right]$.

\section{Soil stiffness according to the Kosecki's method}

Parameters of spring supports, modelling the horizontal cooperation between piles and the surrounding soil, in case of standard pile structures can be determined according to the Kosecki's proposal based on the module of horizontal soil reaction determined by the Equation (10) (Kosecki, 2006). Spring supports, in this method, are placed every $0.50 \mathrm{~m}$.

$$
K_{x}=n_{0} \cdot n_{1} \cdot n_{2} \cdot S_{n} \cdot \kappa \cdot \varphi \cdot E
$$

where:

$n_{0} \quad-$ correction factor for the influence of pile diameter $\left(n_{0}=1.0\right.$ for $0.3 \leq D \leq 1.5, n_{0}=D / 1.5$ for $1.5 \leq D \leq 3.0, n_{0}=D$ for $D \geq 3.0 \mathrm{~m}$ );

$n_{1}, n_{2}$ - coefficients dependent on the diameter and distance between piles $\left(n_{1}, n_{2} \leq 1.0\right)$;

$S_{n} \quad-$ coefficient dependent on the pile technology, assumed $S_{n}=0.9$;

$\kappa \quad-$ coefficient dependent on the shape of the pile cross section;

- coefficient dependent on the durability and repeatability of loads;

- Young's modulus [kPa]. 
Międlarz, K., Więcławski, P. (2018). Application of the Kosecki's method in designing of offshore wind power plants foundation. Acta Sci. Pol. Architectura, 17 (3), 67-77. doi: 10.22630/ASPA.2018.17.3.30

Coefficients $n_{1}$ and $n_{2}$ are determined from following Equations:

$$
\begin{gathered}
n_{1}=0.2 \cdot \frac{R_{1}}{D}+0.4 \leq 1.0 \\
n_{2}=\beta+\frac{(1-\beta) \cdot\left(R_{2}-D\right)}{1.8 \cdot D} \leq 1.0
\end{gathered}
$$

where:

$R_{1}$ - axial distance of piles in the surface perpendicular to the direction of spring supports;

$R_{2}$ - axial distance of piles in the surface parallel to the direction of spring supports;

$D$ - pile diameter $[\mathrm{m}]$;

$D_{0}$ - equivalent pile diameter, equal to $D_{0}=D+1[\mathrm{~m}]$;

$\beta$ - coefficient dependent on the number of rows of piles, assumed $\beta=1$.

\section{RESULTS}

For the purpose of the analysis, a $2 \mathrm{MW}$ turbine was adopted. Dimensions of each component were assumed relying on the guidelines presented in Technical Project Description for Offshore Wind Farms (Energinet.dk, 2015).

The geotechnical aspect in this project is dimensioning the substructure (foundation). In the case of the described monopile, the task was to determine geometry of the pile, i.e. diameter, length and wall thickness, so that the structure could transfer loads safely.

Geotechnical parameters were determined based on cone penetration test data (CPTU) carried out in the Gulf of Gdańsk, $15 \mathrm{~km}$ from shore, at site where water depth was about $12 \mathrm{~m}$.

Loads were determined in accordance with procedures described in chapter "Loads effecting offshore wind farms". Values of measured climatic parameters were obtained from the Institute of Meteorology and Water Management in Gdańsk and based on the publication by Marcinkowski and Szymkiewicz (2016).

Results obtained with the model defined according to the DNV guidelines are shown in Figure 5, while those obtained with the model in which the support springs were defined in accordance with Kosecki's method are shown in Figure 6.

\begin{tabular}{|c|c|c|}
\hline \multirow{3}{*}{ Turbine } & turbine manufacturer & Siemens \\
\hline & turbine model & $\begin{array}{c}\text { SWT-2.3-93 } \\
\text { Offshore }\end{array}$ \\
\hline & capacity & $2.3 \mathrm{MW}$ \\
\hline \multirow{3}{*}{ Operational } & cut-in wind speed & $4.0 \mathrm{~m} \cdot \mathrm{s}^{-1}$ \\
\hline & rated wind speed & $13 \mathrm{~m} \cdot \mathrm{s}^{-1}$ \\
\hline & cut-out wind speed & $25 \mathrm{~m} \cdot \mathrm{s}^{-1}$ \\
\hline \multirow{9}{*}{$\begin{array}{l}\text { Rotor, hub, } \\
\text { blades }\end{array}$} & rotor position & upwind \\
\hline & rotor diameter & $93 \mathrm{~m}$ \\
\hline & rotor area & $6,800 \mathrm{~m}^{2}$ \\
\hline & rotor speed (minimum) & $6 \mathrm{rpm}$ \\
\hline & rotor speed (maximum) & $16 \mathrm{rpm}$ \\
\hline & hub height (AMSL) & $65 \mathrm{~m}$ \\
\hline & blade length & $45 \mathrm{~m}$ \\
\hline & number of blades & 3 \\
\hline & total weight (rotor, hub, blades) & $60 \mathrm{t}$ \\
\hline Nacelle & weight & $82 \mathrm{t}$ \\
\hline \multirow{3}{*}{ Tower } & structure type & tubular, steel \\
\hline & height & $65 \mathrm{~m}$ \\
\hline & weight & $610.08 \mathrm{t}$ \\
\hline \multirow{5}{*}{ Substructure } & diameter & $5.5 \mathrm{~m}$ \\
\hline & wall thickness & $70 \mathrm{~mm}$ \\
\hline & weight & $394.2 \mathrm{t}$ \\
\hline & length driven into sea bed & $30 \mathrm{~m}$ \\
\hline & length above sea bed & $12 \mathrm{~m}$ \\
\hline
\end{tabular}

Table 4. Construction specifications 
Table 5. Soil layers for the analysed static penetration test data

\begin{tabular}{clcc}
\hline \multirow{2}{*}{ Layer No } & \multirow{2}{*}{ Soil type } & \multicolumn{2}{c}{ Depth below the seabed [m] } \\
\cline { 3 - 4 } & & top of the layer & bottom of the layer \\
\hline 1 & clay & 0.00 & 1.00 \\
\hline 2 & sand/sandy silt/clayey silt & 1.00 & 7.10 \\
\hline 3 & clay/silty clay/sandy silt & 7.10 & 9.60 \\
\hline 4 & sand/silty sand & 9.60 & 11.60 \\
\hline 5 & sand & 11.60 & 13.30 \\
\hline 6 & sand/silty sand & 13.30 & 14.80 \\
\hline 7 & silty-clayey sand & 14.80 & 16.10 \\
\hline 8 & silty clay/clay & 16.10 & 21.50 \\
\hline 9 & silty sand/sandy silt & 21.50 & 30.00 \\
\hline
\end{tabular}

Fig. 4. Environmental loads

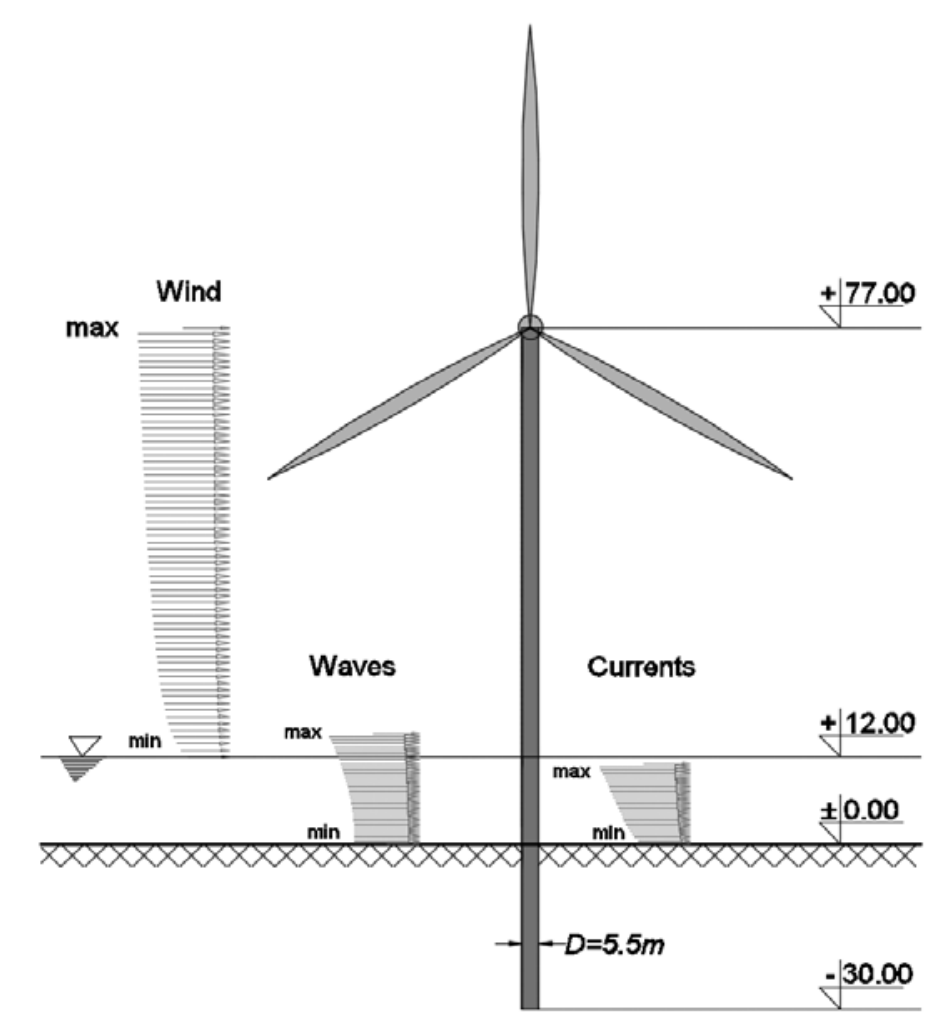

Table 6. Values of environmental loads

\begin{tabular}{llclc}
\hline \multirow{2}{*}{ Load type } & \multicolumn{2}{c}{ Normal operative $\left[\mathrm{kN} \cdot \mathrm{m}^{-1}\right]$} & \multicolumn{2}{l}{ Extreme sea state $\left[\mathrm{kN} \cdot \mathrm{m}^{-1}\right]$} \\
\cline { 2 - 5 } & $\max$ & $\min$ & $\max$ & $\min$ \\
\hline Wind & 0.22 & 0.04 & 1.81 & 1.60 \\
\hline Waves & 0.17 & 0.02 & 8.36 & 0.85 \\
\hline Currents & 9.07 & 2.52 & 46.62 & 16.62 \\
\hline
\end{tabular}




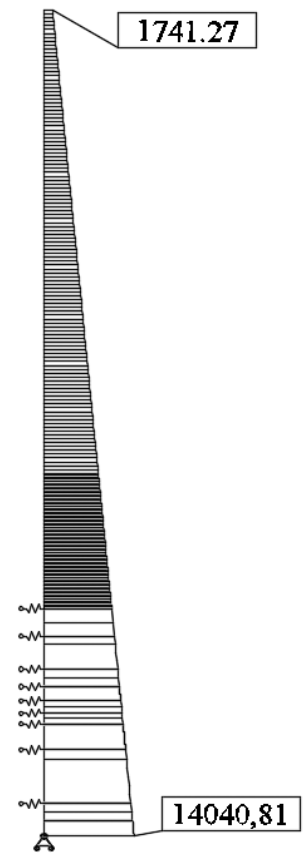

Axial forces $[\mathrm{kN}]$

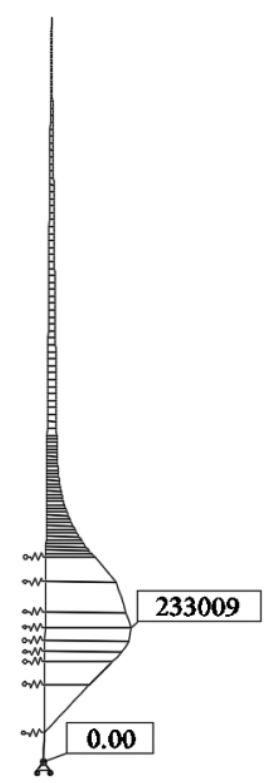

Bending moments $[\mathrm{kNm}]$

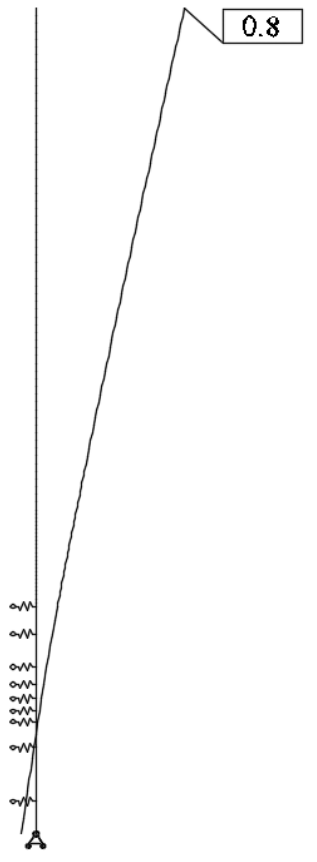

Displacements [m]

Fig. 5. Analysis results for the model according to DNV

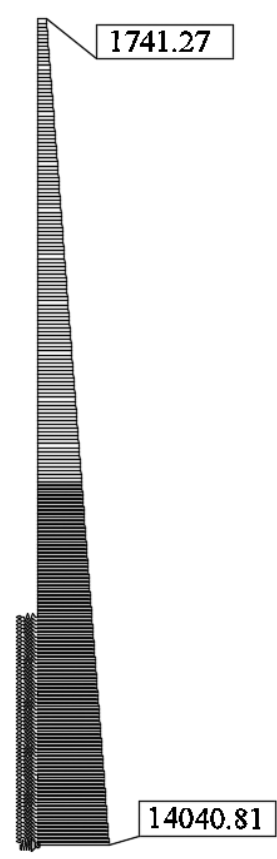

Axial forces $[\mathrm{kN}]$

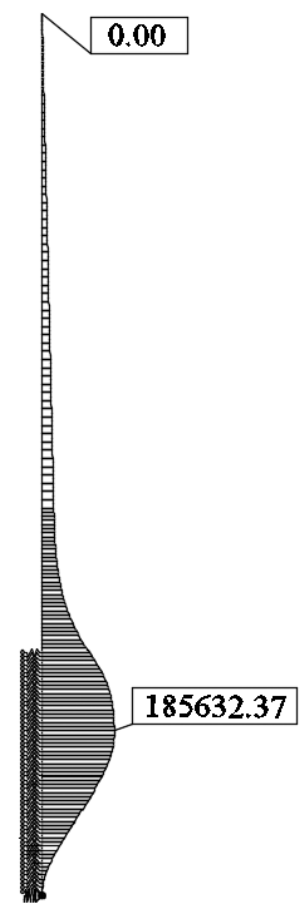

Bending moments [ $\mathrm{kNm}]$

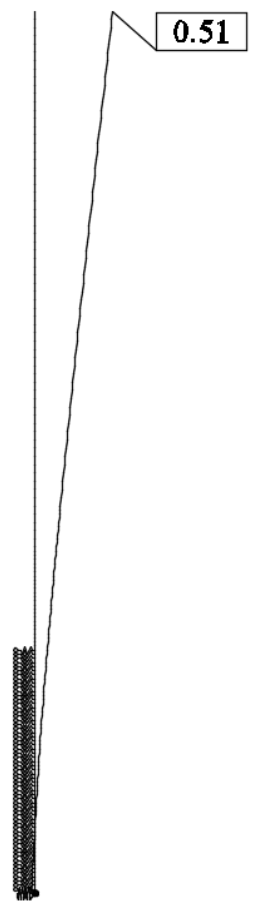

Displacements [m]

Fig. 6. Analysis results for the model according to Kosecki's method 


\section{CONCLUSIONS AND SUMMARY}

Based on the analysis, it appears that in case of offshore monopile wind turbines, main criterion is the serviceability limit state (SLS), especially horizontal displacements of the structure. According to the DNV, permitted displacement is $1 \%$ of the total construction height. In the considered case, the allowed displacement is $1.07 \mathrm{~m}$. The SLS was met in both analyzes. In Kosecki's method, displacements were significantly lower.

The main differences between applied approaches are related to the methodology for defining stiffness of spring supports. They include not only the number of springs in each soil layers, but more importantly the values of soil stiffness $(K x)$. In cohesive soils, the discrepancies of $K x$ are slight (Fig. 7). However, the attention should be paid to the sensitivity of the Norwegian method to changes in the pile diameter. This aspect is not evident in Kosecki's method, it is only visible at a certain depth.

For cohesionless soils, the procedure for determining stiffness of spring supports requires the determination of $p-y$ curves. The best way is to carry out a pile load test, which is rather expensive, especially at design stage. Based on analytical method, the $K x$ values according to DNV are several times higher than those determined with the use of Kosecki's method (Fig. 8).
Kosecki's method is popular and has often been used for calculating piles with standard parameters. In case of very large diameters, obtained results are divergent in relation to the $p-y$ curves method. Mistakes and deviations from proper displacement values increase with pile diameter. The relation to the values obtained according to DNV is shown in Figure 9 and Table 7.

Based on the additional simulation, it was found that the possible scope of Kosecki's method refers to piles with a maximum diameter of $1.5 \mathrm{~m}$. Despite significant discrepancies in the assumptions regarding determination of the $K x$ the theoretical displacement of the top of the structure was the same in both methods for the pile diameter of $1.5 \mathrm{~m}$. It is also important that the trend in the difference in displacements depends on the diameter and is linear.

Designing of offshore wind farms according to national tradition does not exist. The main problem is the lack of standards and guidelines. Scandinavian or American methods are used despite not being fully adapted to the climatic conditions on the Baltic Sea. Based on the conducted analysis, it is stated that after defining appropriate coefficients the Kosecki's method can be used, as an alternative approach, for designing pile foundations for offshore wind farms. Those coefficients, should take into account particularly large pile diameters, specific monopile technology and installation process. This method should also be
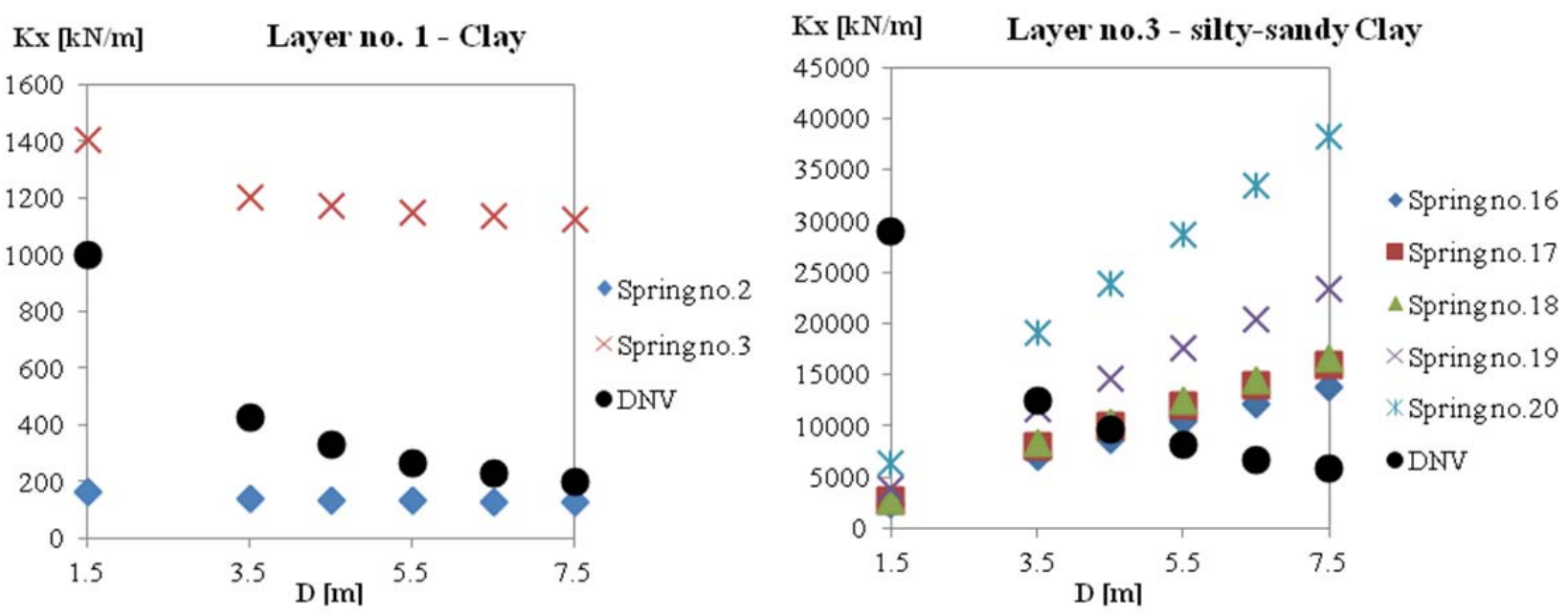

Fig. 7. Soil stiffness in cohesive layers according to DNV and Kosecki's method 
Międlarz, K., Więcławski, P. (2018). Application of the Kosecki's method in designing of offshore wind power plants foundation. Acta Sci. Pol. Architectura, 17 (3), 67-77. doi: 10.22630/ASPA.2018.17.3.30
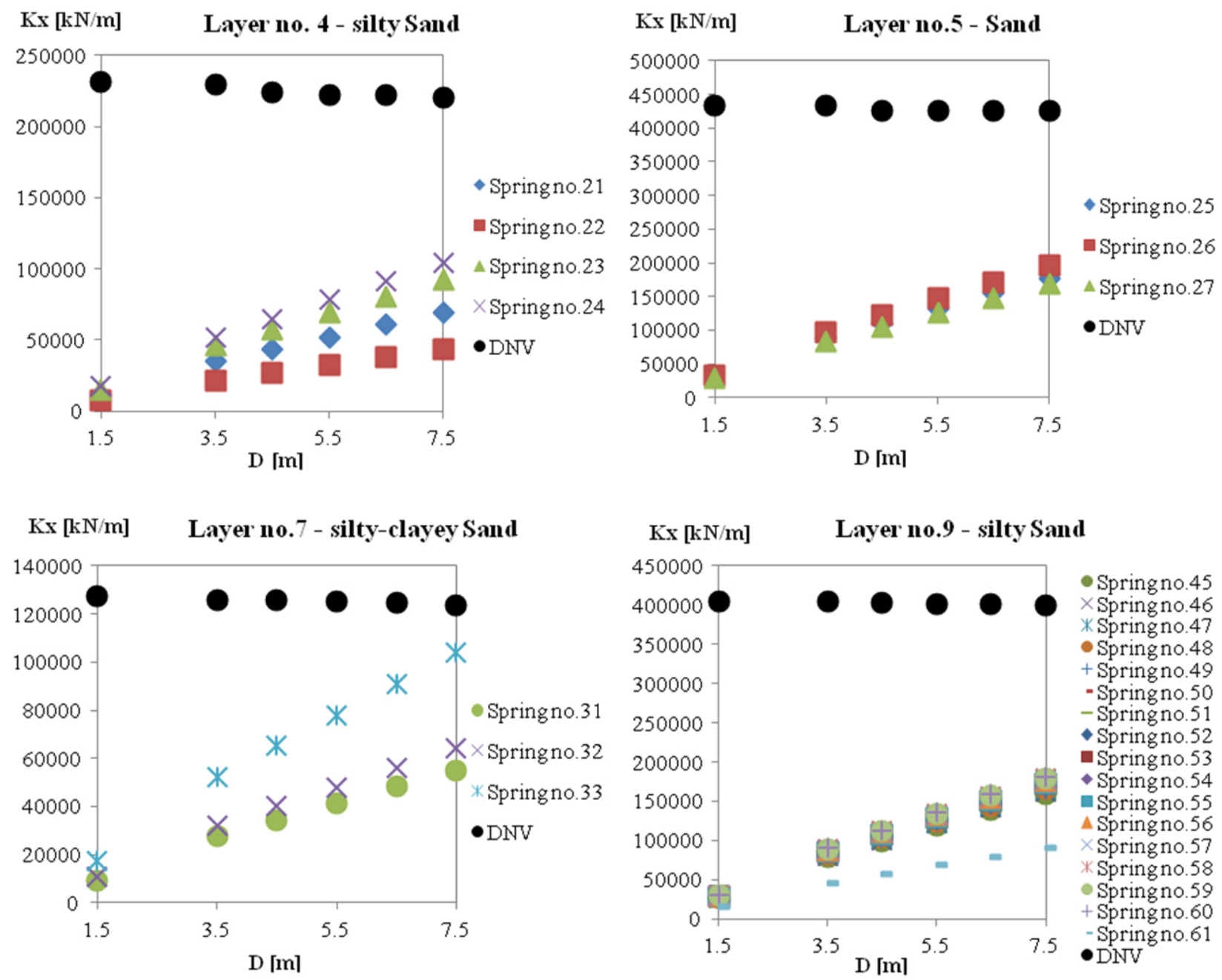

Fig. 8. Soil stiffness in cohesionless layers according to DNV and Kosecki's method

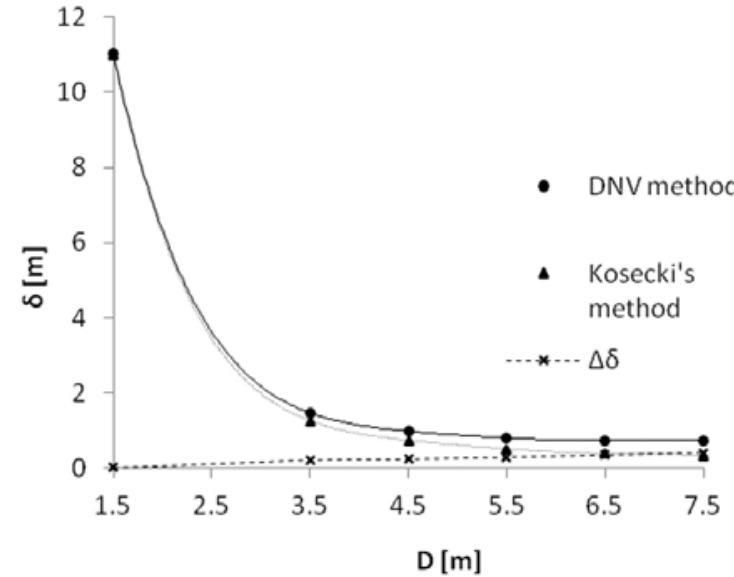

Fig. 9. Relation between horizontal displacement and pile diameter
Table 7. Horizontal displacements

\begin{tabular}{cccc}
\hline $\begin{array}{c}\text { Diameter } \\
{[\mathrm{m}]}\end{array}$ & $\begin{array}{c}\delta(\mathrm{DNV}) \\
{[\mathrm{m}]}\end{array}$ & $\begin{array}{c}\delta(\text { Kosecki }) \\
{[\mathrm{m}]}\end{array}$ & $\begin{array}{c}\Delta \delta \\
{[\mathrm{m}]}\end{array}$ \\
\hline 1.5 & 11.02 & 11.01 & 0.01 \\
\hline 3.5 & 1.47 & 1.26 & 0.21 \\
\hline 4.5 & 0.98 & 0.74 & 0.24 \\
\hline 5.5 & 0.8 & 0.51 & 0.29 \\
\hline 6.5 & 0.74 & 0.39 & 0.35 \\
\hline 7.5 & 0.73 & 0.32 & 0.40 \\
\hline
\end{tabular}


calibrated to local soil conditions. The advantage of Kosecki's method is a clear, analytical determination of the characteristics of spring supports.

\section{REFERENCES}

American Petroleum Institute (2000). Recommended practice for planning, designing and constructing fixed offshore platforms - working stress design (RP 2A-WSD).

Chen, W.F. \& Duan, L. (2003). Bridge Engineering: Substructure Design. Boca Raton, FL: CRC Press.

Det Norske Veritas (1992). Classification Notes No. 30.4 Foundations. Oslo: Det Norske Veritas.

Det Norske Veritas (2007). Recommended Practice for Environmental Conditions and Environmental Loads (DNV-RP-C205). Norway: Hovik.

Det Norske Veritas (2010). Design and manufacture of wind turbine blades, offshore and onshore turbines ( DNV-DSJ102). Norway: Hovik.

Det Norske Veritas (2014). Design of Offshore Wind Turbine Structures (DNV-OS-J101). Norway: Hovik.
Energinet.dk. (2015). Technical Project Description for Offshore Wind Farms (200 MW).

International Electrotechnical Commission (2005). IEC 61400-1: Wind turbines. Part 1: Design requirements.

International Electrotechnical Commission (2009). IEC 61400-3: Wind Turbines. Part 3: Design Requirements for Offshore Wind Turbines. Tech. Rep.

Kosecki, M. (2006). Statyka ustrojów palowych. Zasady obliczania metoda uogólniona i fundamentów ptytowo-palowych metoda podłoża dwuparametrowego. Szczecin: PZITB Oddział Szczecin.

Leite, O.B. (2015). Review of design procedures for monopole offshore wind structures (master thesis). University of Porto.

Marcinkowski, T. \& Szmytkiewicz, P. (2016). Morskie farmy wiatrowe: określenie parametrów środowiskowych oddziaływujących na planowane elektrownie wiatrowe w obszarze Polskiej Wyłącznej Strefy Ekonomicznej. Inżynieria Morska i Geotechnika, 5, 272-278.

van der Tempel, J. (2006). Design of support structures for offshore wind turbines. PhD thesis. TU Delft, The Netherlands.

\section{ZASTOSOWANIE METODY KOSECKIEGO W PROJEKTOWANIU POSADOWIENIA MORSKICH ELEKTROWNI WIATROWYCH}

\section{STRESZCZENIE}

Koncepcja morskich elektrowni wiatrowych została dobrze rozwinięta w wielu krajach europejskich. Obecnie nie projektuje się morskich elektrowni wiatrowych zgodnie z krajowymi tradycjami. Głównym problemem jest brak standardów i wytycznych. Stosowane są metody skandynawskie lub amerykańskie, które nie są w pełni dostosowane do warunków panujących na Morzu Bałtyckim. Artykuł skupia się na projekowaniu monopali, ponieważ są one obecnie najczęściej stosowanym rodzajem fundamentów morskich elektrowni. Wyniki analizy, przeprowadzonej zgodnie ze standardowymi metodami służącymi projektowania monopali pod turbiny wiatrowe, porównano z wynikami uzyskanymi metodą Koseckiego. Analizowana w artykule geometria wykracza poza zakres zdefiniowanych współczynników uwzględniających kształt i technologię pala, służących do wyznaczania sztywności podpór sprężystych. Przyjęte etapy analizy pozwoliły określić granicę stosowalności metody Koseckiego dla monopali obciążonych siłami poziomymi.

Słowa kluczowe: fundamenty palowe, monopale, morskie elektrownie wiatrowe, energia wiatrowa 